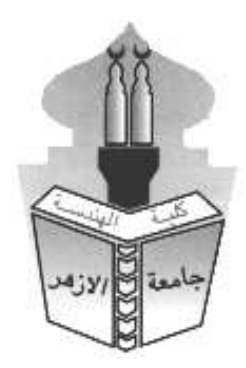

\title{
BURNING UNIT ENHANCEMENT USING MULTIPLE HEAT EXCHANGER CONFIGURATIONS Mahmoud Elsergany ${ }^{1,}$, , Abdel Salam H A ${ }^{1}$, Mahmoud Awaad ${ }^{1}$, W. Shaaban ${ }^{1}$
}

\author{
${ }^{1}$ Mechanical Power Engineering Department, Faculty of Engineering, Mansoura University, El-
} Mansoura 35516, Egypt

Received :6 June $2021 \quad$ Accepted:19 July 2021

\begin{abstract}
Incineration is a thermal treatment process which mainly used to treat the waste material and convert it to ashes, flus gases and thermal energy. This technique has a positive impact on the environment as it successfully addresses the dangerous waste materials. Incorporating a heat exchanger with the incinerator was proved to have a high positive impact on the overall performance. Numerical and/or experimental investigation of incorporating heat exchanger with incinerator could be used to study the system performance. The commercial software, Ansys 2020, was used in the current work to analyze the various parameter of the heat exchanger such as heat transfer, pressure drop, quantity of heat, velocity, and temperature. The present paper mainly focusses on the temperature distribution and the efficiency of the heat exchanger and improving the exhaust gases' conditions in the incineration. The current work shows the validity of the outlet cooling water to be used as a source of heat. The proposed design shows an excellent cooling for the exhaust gases compared to that of current design. The results of the current work show that the outlet temperature of the cooling water for the proposed heat exchanger is dramatically higher than that of the current heat exchanger. For instance, at the flow rate of $0.4 \mathrm{~kg} / \mathrm{s}$, the outlet cooling water temperatures were found to be $70^{\circ} \mathrm{C}$ and $30^{\circ} \mathrm{C}$, for the proposed and the old heat exchanger, respectively.
\end{abstract}

KEYWORDS: Incineration; Heat exchanger; CFD Modeling; Exhaust gases. 


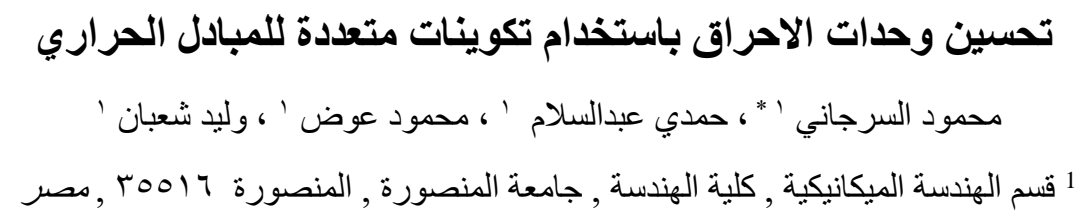

Email: Eng_mahmoudelsergany@yahoo.com : البريد الاليكتروني للباحث الرئيسى :

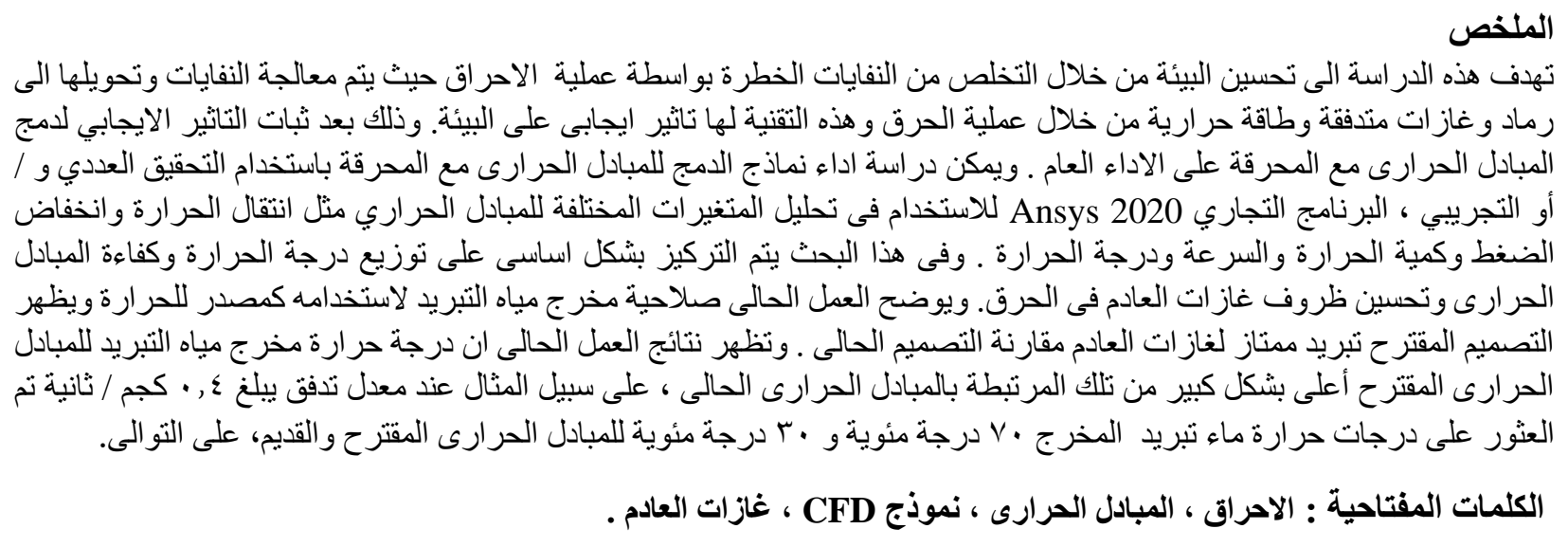

\section{INTRODUCTION}

Slaughterhouse wastes are the inedible portions of animals which derived from the meat production, blood, and other animal byproducts. A large amounts of slaughterhouse waste are produced all over the world, and hence their disposal is a serious challenge for meat/poultry processing plants. Incineration process is considered the thermal disposal of carcasses using supplementary fuel as natural gas or propane. Incinerators could be generally classified as; incinerator for municipal waste, hospital disposal incinerator and slaughterhouse incinerators, while it could be specifically classified into direct flame and catalytic-type incinerators [1]. This plant has two major issues, the first one is the emission, while the second is energy recovery.

In the last decades, a lot of efforts have been conducted on recovering the waste heat and lowering the emissions. [2] developed an integrated model to exchange heat between incineration and industries in city scale and concluded that about $45.2 \%$ of waste heat could be utilized and $\mathrm{Co}_{2}$ emission was reduced. A novel medical incinerator was developed by [3], and the results showed a very good suitability for neutralization for the medical wastes and the flue gases purifications. [4] presented a result of thermal treatments of meat and bones and concluded that the selection of the process parameters helps to obtain ash with controlled composition of macro and micronutrients and sanitary safe. A very good literature review was introduced by [5] on the integration of municipal waste incinerated bottom ash to be used as a raw material in several markets and this review showed that it could be used as an adsorbent material to remove hazard elements.

On the other hand, heat energy is a very important issue to be studied and optimized. [6] presented a review on the techniques where liquids and gases have been disposes of during incineration and the values of energy recovered to be used in the plant. [7] details experimentally three different oil sludge wastes in fluidized bed incineration, and got a high combustion efficiency, and it was concluded that it was not only successful in removing toxicity, but also reduced the volume to be disposed. [8] provided a very good study on the energy recovery optimization and concluded that extraction of low-pressure steam besides heat exchanger allowed higher level of energy recovery than extracting high pressure steam directly.

The current work presents two major points, the first one is that presenting a new design of the incinerator which is near that was presented in [1], but with $10 \mathrm{~m}$ stack rather than $6 \mathrm{~m}$ which reduce the emission and improve the performance. The second point is that the incinerator was thermally analyzed with and without 
the heat exchanger. This paper complete experimental work [9] that can be used to describe the relation between time and temperature and analysis flue gases. In this paper can be used Ansys software to analysis simulation and to get better design heat exchanger can be used in incineration and get better improvements can be used to get better performance in incineration.

\section{MATERIALS AND METHODS}

\subsection{Incinerator Design Without Heat Exchanger}

The incinerator was designed to be in Mansoura and Damanhur for large animal slaughterhouse for infectious disposal meat up to $400 \mathrm{~kg}$ charging capacity. The concept of the incinerator design depends on burning infectious meat at high temperature and its relationship with time and the heat balance in the incinerator. Design of incinerator depends on some major points, which should be taken into consideration such as incinerator charging capacity, fuel consumption burning, temperature, emission limitation. The design of incinerator without heat exchanger is shown in Fig. 1 with the installed instruments for measurement purposes. The proposed design describes the operation procedure of the incinerator and illustrates the position of the primary and secondary burners and the thermocouples to measure the temperature of primary and secondary burners and the temperature flue gases. It also describes the circulation of flue gases from inside the incinerator to the stack. The design shows how we build the incinerator, and a thermal brick was used which allows high temperature in the incinerator. The design shows the control panel which is used to control the two burners.

\subsubsection{Incinerator Chambers}

Incinerator consisting of four chambers, the main chamber, the secondary chamber, the intermediate chamber, and the final chamber. The volume of main chamber is $2.4 \mathrm{~m}^{3}$, which was designed for burning infectious disposal meat for about $400 \mathrm{~kg}$ chamber capacity. The secondary burner is located upward the secondary chamber. The secondary burner completes the combustion of the flue gases and delay the circulation flue gases in the incinerator. The intermediate chamber volume is $1.8 \mathrm{~m}^{3}$, which is located between main and secondary chambers. The final chamber is located between secondary chamber and the exit flue gases to the stack. The main door is in the frontal side of incinerator from which the infectious meat is fed from it. The main door is made from thermal brick with a steel sheet cover.

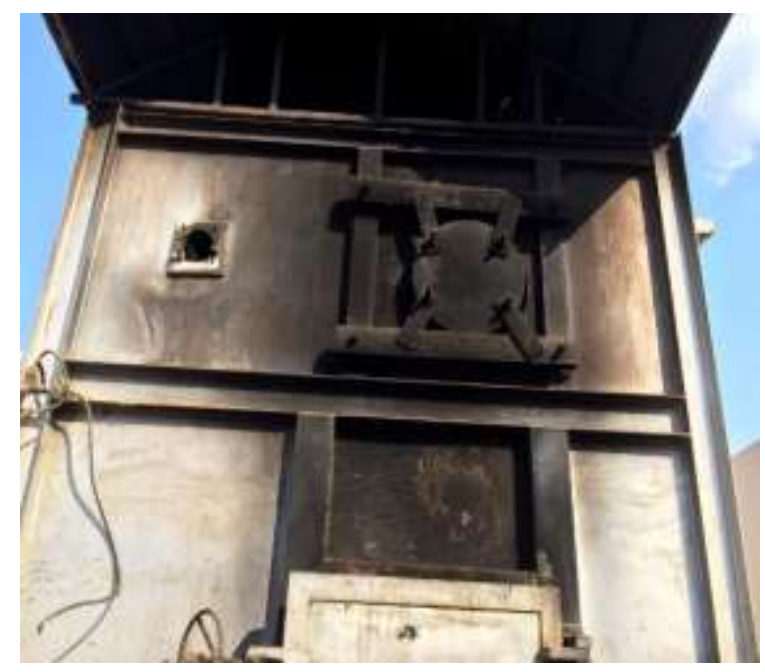

Figure 1: Incinerator frontal view 


\subsubsection{The Main Door}

Figure. 2 shows the main door of the incinerator which was designed for smooth moving, with open and close actions. The main door has $0.8 \mathrm{~m}$ width and $1.2 \mathrm{~m}$ height, that was made of thermal brick which is supported by steel panel from both sides. It has two detailed from the right side and has iron handle to make sure that the door is Correctly closed.

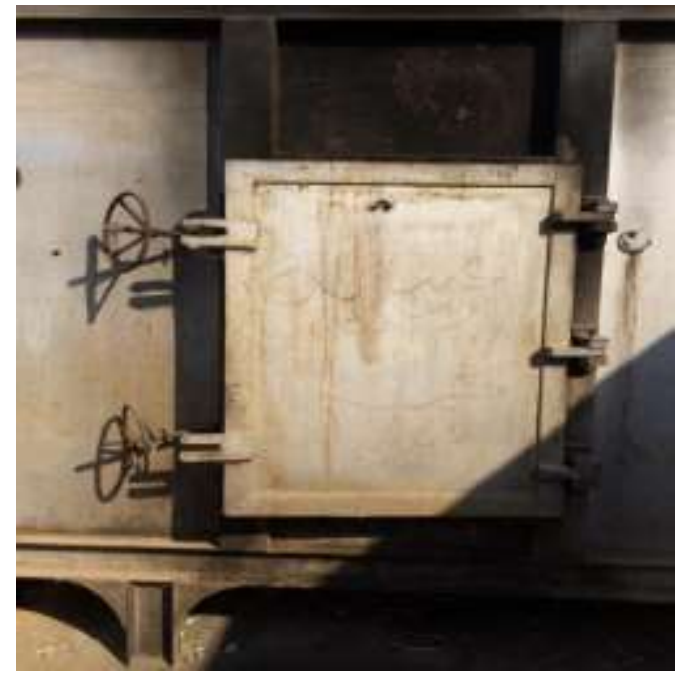

Figure 2: Incinerator main door

\subsubsection{Primary and secondary burners}

The primary burner, as shown in Fig. 3, is in the back side of the primary chamber and at front of the main door to burn the infectious meat, and it was fixed in horizontally. It consists of internal components such as, the control circuit as shown in Fig. 4, the blower, the ignition, the fuel socket, and the iron tube fixed on the burning hole. The condition of the flame is designed to be premixed. On the other hand, the secondary burner is in the front of the incinerator and in front to the secondary chamber. It is located at upper left of the main door, and its design is like that of the primary burner, except that the secondary burner is controlled for limiting condition. It was designed to burn the flue gases and make sure that the $\mathrm{No}_{\mathrm{x}}$ is completely separated.

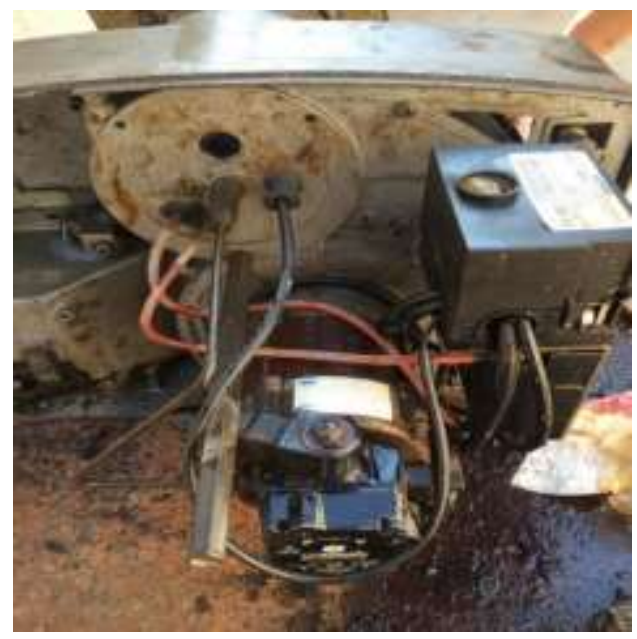

Figure 3: Internal view for the burners 

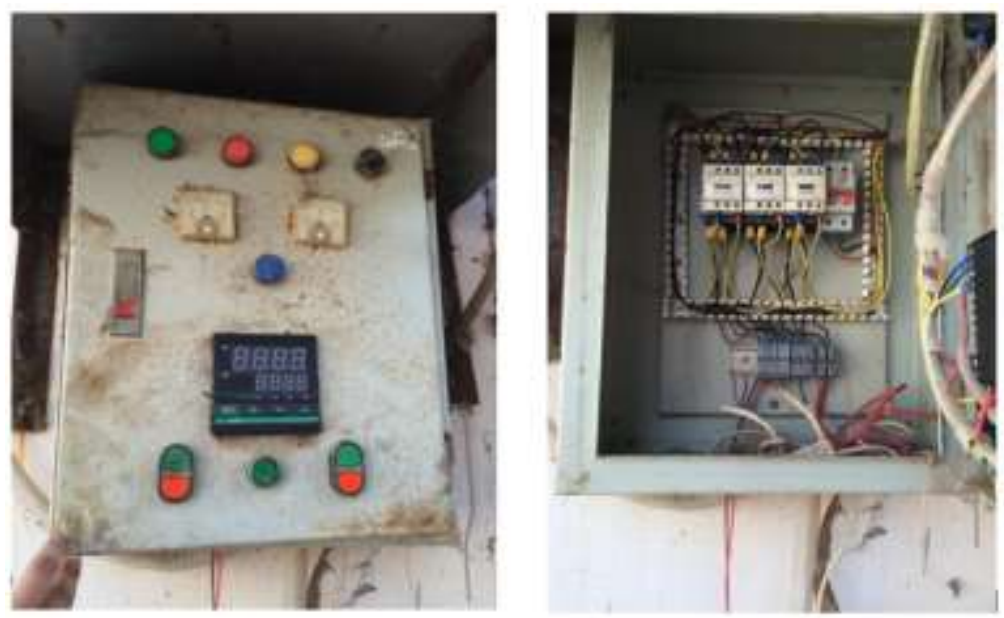

Figure 4: Outside and inside view of the control unit

\subsubsection{Carbon Filter}

The carbon filter is located at incinerator stack to remove heavy metals and dioxin from the flue gases. The carbon filter was designed to be removable to be changed with maintenance.

\subsubsection{Temperature And Emission Measuring Instruments}

The temperatures were measured using thermocouples through the three fabricated holes, which were distributed at the desired locations along the incinerator. The thermocouples were put in these holes through which the temperature could be measured. It was connected to the control panel to be displayed on the digital temperature recorder. Emission concentrations were measured using the combustion analyzer, which used to calculate carbon dioxide concentration, excess air and combustion efficiency and integrated with a computer software to print the results. These measurements are mainly to indicate the quality of the incinerator, and to compare its operating performance with and without heat exchanger.

\subsubsection{Incinerator operating procedures}

There are some precautions to be taken into consideration for refractories safety and to prevent thermal shocks, that is before the incinerator start up the refractories should be well dried, according to a certain thermal program. According to this program, a gradual temperature increases in the incinerator for twelve hours followed by a similar period of temperature decrease. The incinerator operation should follow the following procedures: (1) check the burners, (2) feed the incinerator with the infectious meat in the main chamber and carefully close the door, (3) start the secondary burner until the temperature reaches $1000{ }^{\circ} \mathrm{C}$ as recorded by the thermocouples monitors, (4) start the primary burner, (5) start the incineration cycle which lasts about four hours and after the cycle is completed the primary burner should be shut down firstly and then the secondary burner.

\section{DESIGN MODIFICATION}

\subsection{Heat Exchanger}

Heat exchanger was used, as shown in Fig. 5 to improve the efficiency of the incinerator, as it could recover part of the thermal energy from the exhaust gases. It is located just before the stack to gain heat from the flue gases exhausted from the secondary chamber. Furthermore, it is used to reduce the temperature of flue gases and consequently reduce its effect on the environment. It consists of two metal headers, and the coldwater inlets from main water socket then the hot water outlets from the heat exchanger after heating process to be used in slaughterhouse. It has 34 standard steam tubes that have $22 \mathrm{~mm}$ inner diameter, $2 \mathrm{~mm}$ thickness and $2 \mathrm{~m}$ length. It also improves the shape of the flue gases which becomes looked like steam vapor. 


\subsection{Position Of Burner}

The primary burner alignment was studied in a modified position, as it was located at an inclined position rather than horizontal alignment. This modification was proposed to study the effect of burner position on the time of incineration and the sample temperature.

\subsection{Stack height}

The effect of stack length was studied to compare the incinerator performance at different stack heights. The stack's height was changed from $600 \mathrm{~mm}$ to $1000 \mathrm{~mm}$. The stack is fixed in the floor and relates to incinerator with tube exit flue gases to the stack.

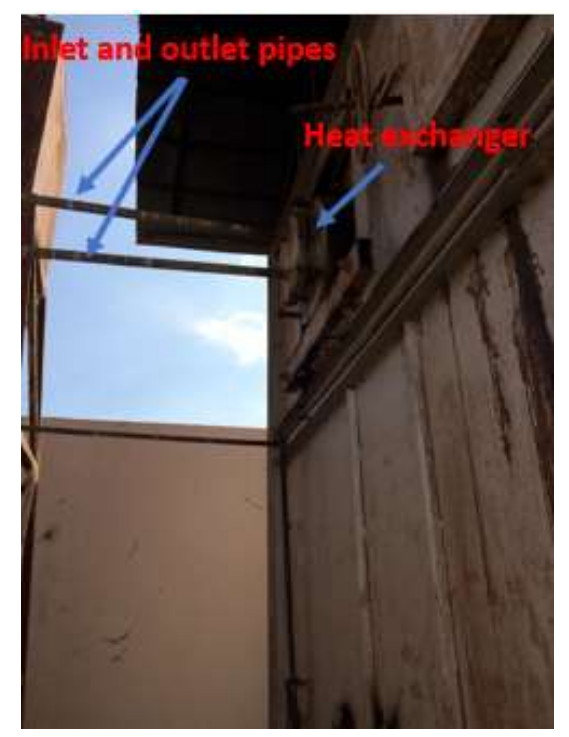

Figure 5: Incinerator with heat exchanger

\section{Numerical Solution}

In this section, the governing equations, modeling process, validation and mesh dependence test will be introduced to illustrate the numerical solution in the current work. The current work introducing an efficient design for the heat exchanger to be used with the introduced incinerator, to reduce the exhaust gases' temperature and supply hot water to be used as a heating source, which is available at the exit of the desired system. The software is solving the governing equations using finite volume technique, and the pressurevelocity coupling method was used in the current work.

\subsection{Governing Equations}

The system is governed by the following governing equations:

Mass conservation:

$$
\nabla \cdot \vec{U}=0
$$

Momentum equation:

$$
(\overrightarrow{\mathrm{U}} \cdot \nabla) \overrightarrow{\mathrm{U}}=-\frac{1}{\rho} \nabla P+v \nabla^{2} \overrightarrow{\mathrm{U}}
$$

Energy equation: 
$\overrightarrow{\mathrm{U}} . \nabla \mathrm{T}=\alpha \nabla^{2} \mathrm{~T}$

$\overrightarrow{\mathrm{U}}, P, \mathrm{~T}, \rho, v$ and $\alpha$ are the velocity vector, pressure, temperature, density, viscosity, and thermal diffusivity, respectively.

The water produced volume which is defined as the amount of hot water available after the incinerating process which lasts $4 \mathrm{hr} /$ day could be calculated as follows:

$$
\mathrm{V}=\dot{\mathrm{m}} \mathrm{t} / \rho
$$

$\mathrm{V}, \dot{\mathrm{m}}$, and $\mathrm{t}$ are the volume of the produced hot water, water mass flow rate and the operating time of the incinerator $(4 * 3600 \mathrm{~s} /$ day $)$.

\subsection{Modeling Process}

The numerical solution is introduced in this section, which was carried out using the commercial software (Ansys 2020). This software solves the governing equations using finite volume method after defining the model, mesh, and reasonable boundary conditions. The errors were set to be 10e-6 for continuity and momentum equations, and 10e-9 for energy equation, to assure accurate results. First, the numerical solution is validated with another experimental results to show the validity of the model. Then a mesh dependence test is carried out to obtain a solution that is not affected by the mesh size. Finally, the boundary and operating conditions were used to get the results of the proposed system. The operating and boundary conditions are listed in Table 1. Figure 6 shows the old design drawing and Fig. 7 shows the proposed design drawing, which are used for simulation process. The old system contains only one pipe, four passes with 3 $\mathrm{cm}$ inner diameter and the exhaust gases channel is $100^{*} 100 \mathrm{~cm}^{2}$ cross section and $200 \mathrm{~cm}$ length. On the other hand, the proposed design consists of 55 inner tubes with $3 \mathrm{~cm}$ inner diameter and $100 \mathrm{~cm}$ length for water flow.

Table 1: Operating and boundary conditions

\begin{tabular}{|c|c|c|}
\hline Parameter & Value & unit \\
\hline Water mass flow rate & $0.1-0.5$ & $\mathrm{Kg} / \mathrm{s}$ \\
\hline Exhaust gases mass flow rate & 0.106 & $\mathrm{Kg} / \mathrm{s}$ \\
\hline Water inlet temperature & 27 & ${ }^{\circ} \mathrm{C}$ \\
\hline Exhaust gases inlet temperature & 1100 & ${ }^{\circ} \mathrm{C}$ \\
\hline Water specific heat & 4182 & $\mathrm{~J} / \mathrm{kg} \mathrm{K}$ \\
\hline Exhaust gases specific heat & 1046.6 & $\mathrm{~J} / \mathrm{kg} \mathrm{K}$ \\
\hline Water density & 1000 & $\mathrm{Kg} / \mathrm{m}^{3}$ \\
\hline Exhaust gases density & 0.4 & $\mathrm{Kg} / \mathrm{m}^{3}$ \\
\hline
\end{tabular}



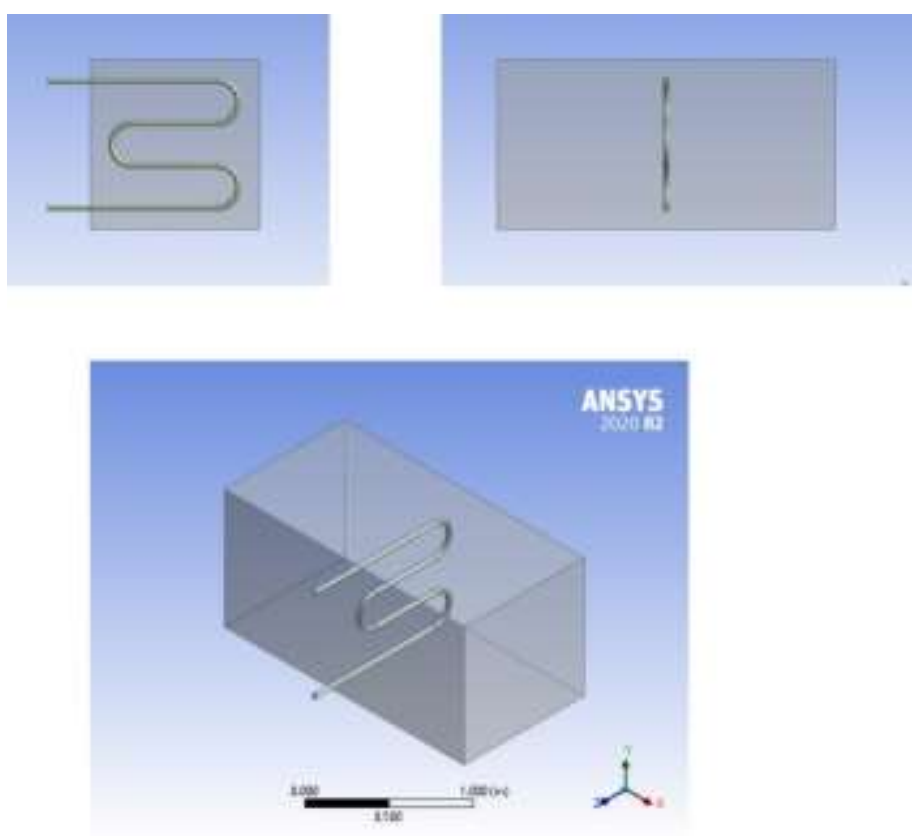

Figure 6: Old design drawing used for simulation.
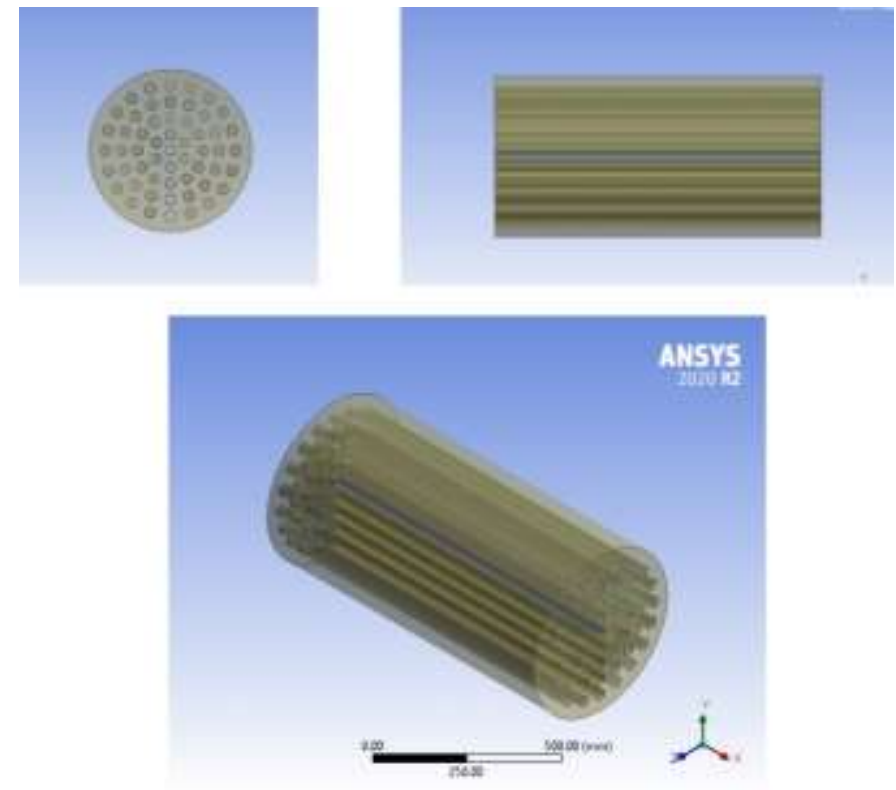

Figure 7: Proposed design drawing used for simulation

\subsection{Validation}

The current simulation work is validated with the experimental work of [9]. The selected cases are the counter and parallel flow cases without twisted tape. As could be seen from Fig. 8. The results show a very good agreement between the used model and the experimental results of [9] with a maximum error of $1.77 \%$ in the cold fluid outlet temperature. 


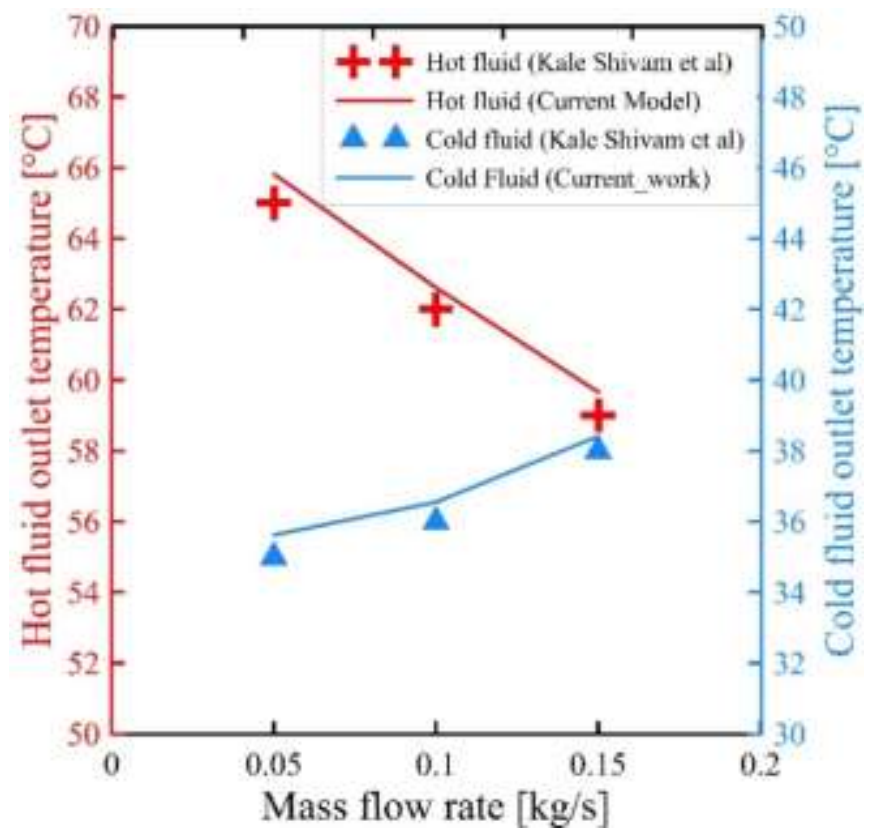

Figure 8: Validation of the current work with experimental results from [9]

\subsection{Mesh Dependence Test}

The mesh dependence test should be carried out for any numerical solution to get a solution that is not dependent on the number of cells. At first a coarse mesh, which is a combination between tetrahedral and hexahedral types, are created (using the software default settings) with 1000000 elements for the proposed design at $0.3 \mathrm{~kg} / \mathrm{s}$ water mass flow rate. And the outlet cold fluid (water) temperature was checked as it is the target parameter. After that, the number of cells has been increased up to the fine mesh of 5000000 elements, where the outlet water temperature no longer changes with the mesh size. Table 2 shows the results of the mesh dependence test, and the selected case was case 4, with a relative error of $0.11 \%$. Moreover, the used mesh for old design and the proposed design are presented by Fig. 9 (a) and (b), respectively.

Table 2: Mesh dependence test

\begin{tabular}{|c|c|c|c|}
\hline Case & $\begin{array}{c}\text { Number of } \\
\text { elements }\end{array}$ & $\begin{array}{c}\text { Water outlet } \\
\text { temperature }\left[{ }^{\circ} \mathbf{C} \text { ] }\right.\end{array}$ & \%Error \\
\hline 1 & 1000000 & 74.56 & 3.5 \\
\hline 2 & 2000000 & 75.81 & 1.9 \\
\hline 3 & 3000000 & 76.54 & 0.94 \\
\hline 4 & 4000000 & 77.184 & 0.11 \\
\hline 5 & 5000000 & 77.27 & --- \\
\hline
\end{tabular}


(a) Old Design

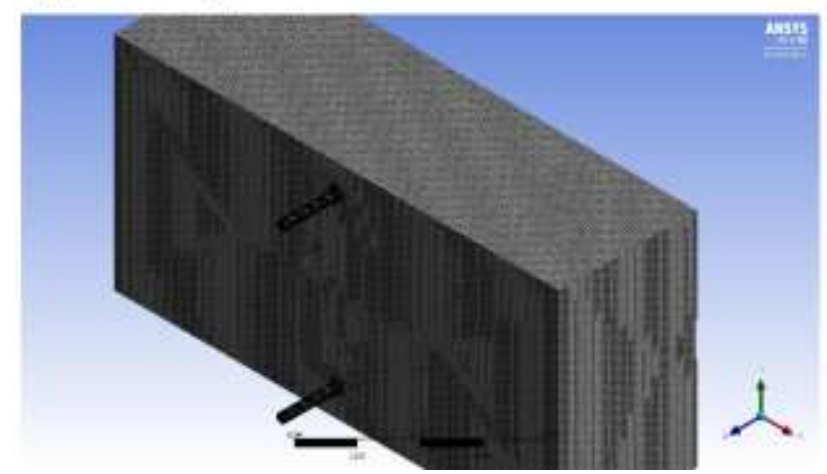

(b) Proposed Design

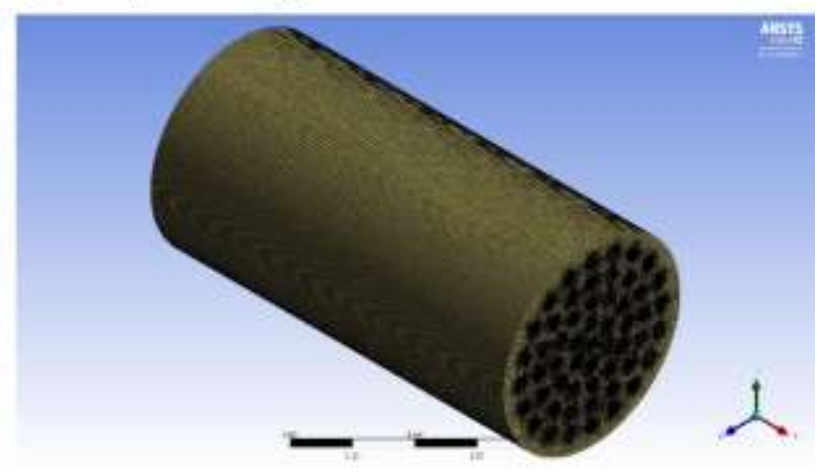

Figure 9: The used meshes for (a) old design (b) proposed design

\section{RESULTS AND DISCUSSION}

The results of the numerical work are presented to compare the thermal performance of the old design (current heat exchanger) and the proposed heat exchanger. As could be clearly seen from Fig. 10, the proposed design outperforms the old design regarding the water outlet temperature. The water exits from the proposed design with much higher temperature than that of the old design. Fig. 10 shows the effect of water mass flow rate on the water exit temperature. For example, at water mass flow rate of $0.3 \mathrm{~kg} / \mathrm{s}$, the water outlet temperature was about $80{ }^{\circ} \mathrm{C}$ and $32{ }^{\circ} \mathrm{C}$ for the proposed design and old design, respectively. Moreover, based on the energy conservation concept, increasing the water flow rate is decreasing the water outlet temperature. Figure 11 shows the effect of water flow rate on the exhaust gases outlet temperature. The proposed design shows an excellent cooling for the exhaust gases compared to that of current design. This figure shows that the average outlet gas temperature is about 1050 and $450{ }^{\circ} \mathrm{C}$ for current and proposed design, respectively.

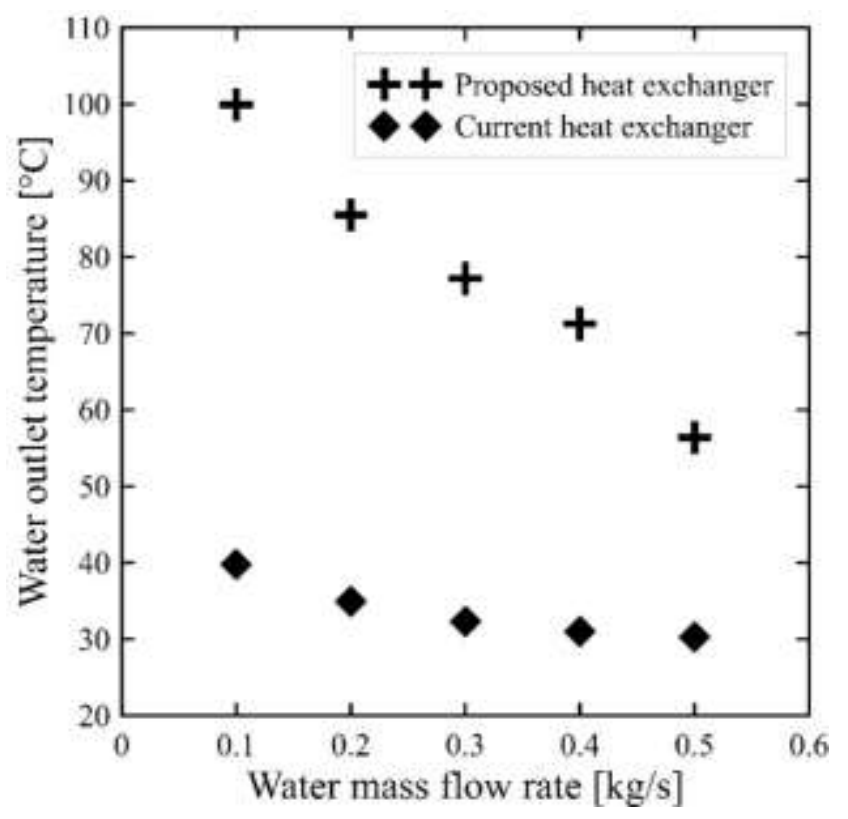

Figure 10: Effect of water flow rate on the water outlet temperature for both current and proposed heat exchangers 


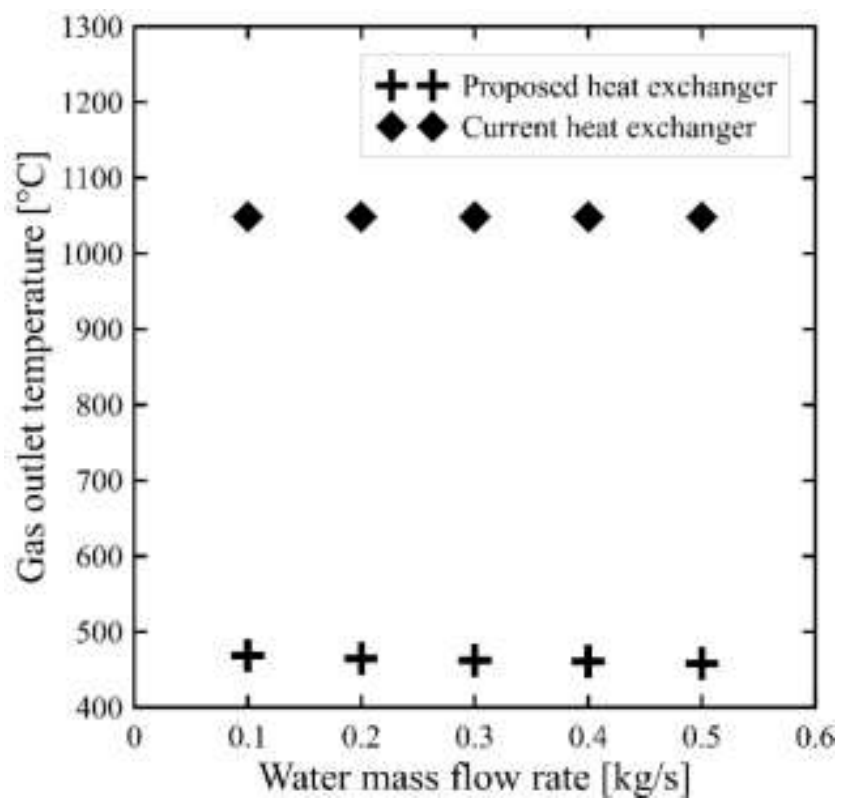

Figure 11: Effect of water flow rate on the exhaust gases outlet temperature for both current and proposed heat exchangers

The incinerator is operating $4 \mathrm{hr} /$ day, and so the produced hot water capacity is limited to this value. Figure 12 shows the effect of water flow rate on the daily produced hot water and the corresponding temperature for the two heat exchangers. For instance, at $0.4 \mathrm{~kg} / \mathrm{s}$ water mass flow rate, the old heat exchanger and proposed heat exchanger would produce $5.76 \mathrm{~m} 3$ of water at $31^{\circ} \mathrm{C}$ and $71{ }^{\circ} \mathrm{C}$, respectively. Figure 12 shows the quantity of hot water available after the complete operation of the incinerator $(4 \mathrm{hr} /$ day $)$ according to Eqn. 4.

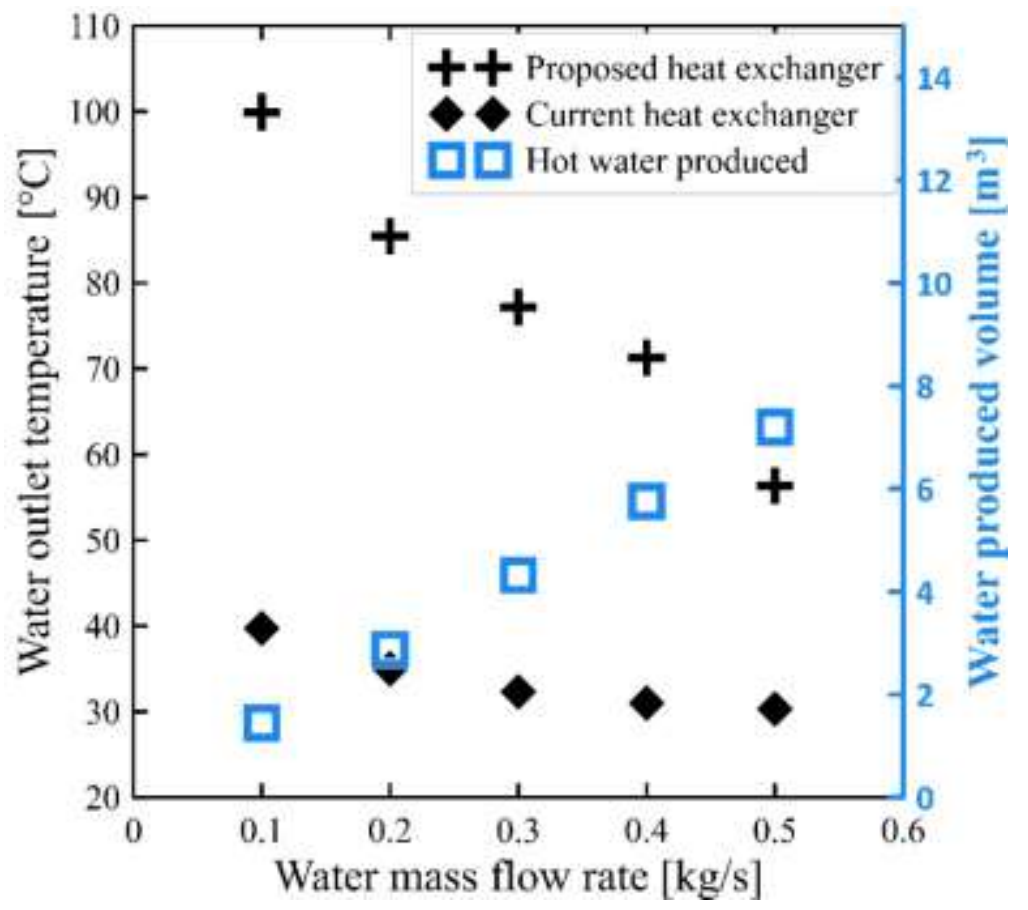

Figure 12: Effect of water mass flow rate on the produced capacity and temperature 
The physical concept regarding the higher performance of the multi tube heat exchanger (proposed design) than that of single tube heat exchanger (current design), is that the extremely higher surface area of the former compared to the latter. This higher surface area allows more heat transfer from the exhaust gas to the water in the tubes according to the following equation [10]:

$\mathrm{Q}=\mathrm{UA} \Delta \mathrm{T}_{\mathrm{m}}$

$\mathrm{U}, \mathrm{A}$, and $\Delta \mathrm{T}_{\mathrm{m}}$ are the overall heat transfer coefficient, total surface area, and logarithmic mean temperature difference, respectively.

The temperature and velocity contours are also presented in this section to show the realistic of the model, and to provide an indication for the velocity and temperature distribution at different sections. Figures 13 and 14 show the temperature and velocity contours at different cross sections for both current and proposed designs, respectively.

On the other hand, the pressure drop within the tubes for the current and proposed heat exchanger are illustrated in Figure 15. Although, the proposed design has more tubes than the current design, the pressure drop is lower as could be seen from Figure 15. This could be attributed to the decreased flow velocity through the tubes in the proposed design, as the same mass flow rate was distributed to 55 tubes of the same diameter. The exhaust gas pressure drop (in the shell side) was affected in the proposed heat exchanger by the increased number of tubes. The proposed design recorded, and average pressure drop of $202.7 \mathrm{~Pa}$ whereas, the current design recorded 35.8 $\mathrm{Pa}$.

$$
\text { (a) Cross section temperature contour }
$$
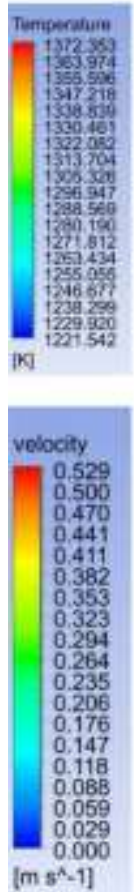

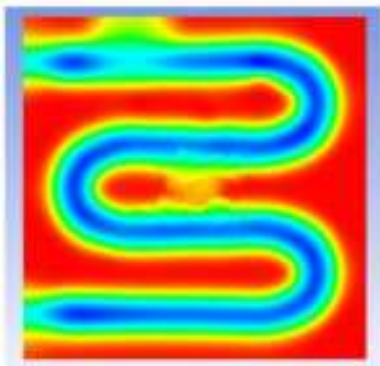

(c) Cross section velocity contour

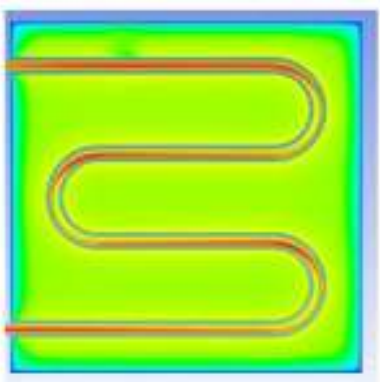

(b) Temperature contour along flow dircetikn

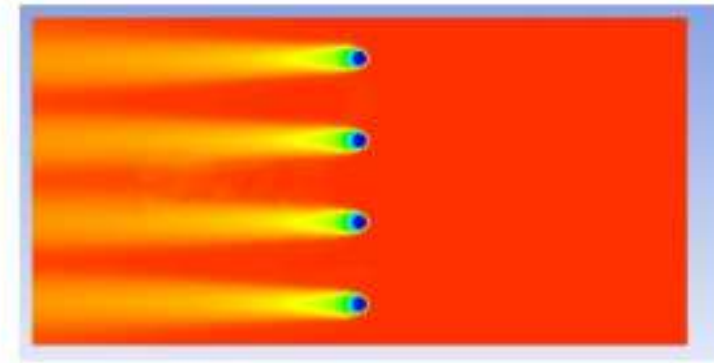

(d) Velocity contour along flow direction

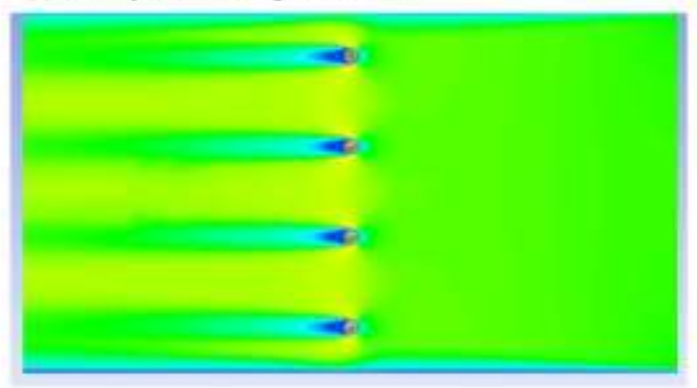

Figure 13: Temperature and velocity contours at different sections for current heat exchanger 
(a) Cross section temperature contour
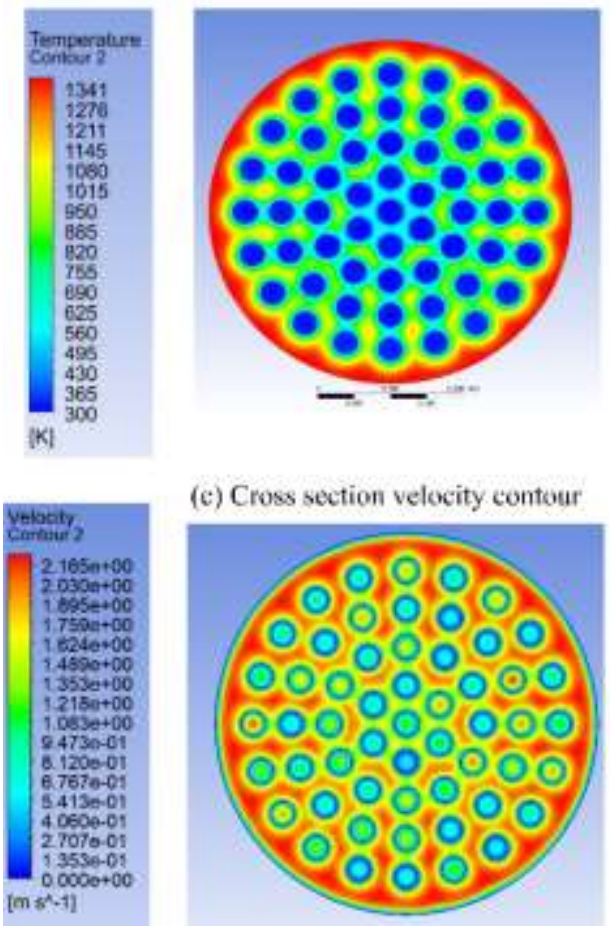

(c) Cross section velocity contour

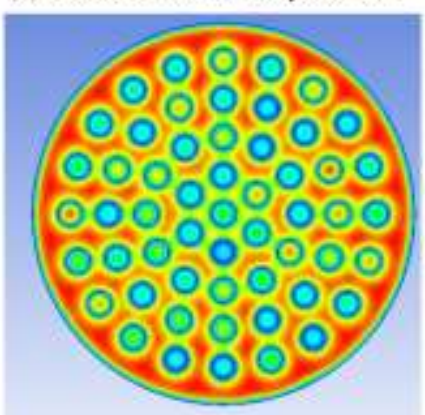

(b) Temperature contour along flow direction

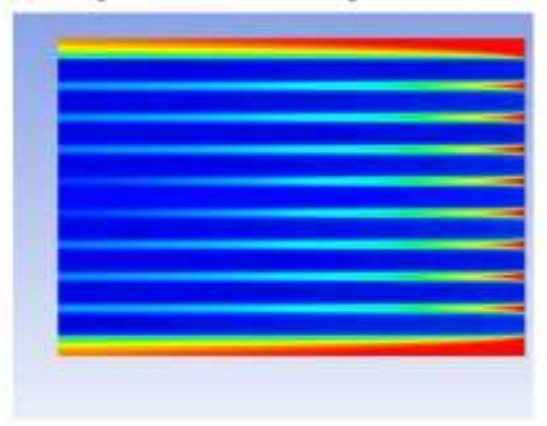

(d) Velocity contour along flow direction

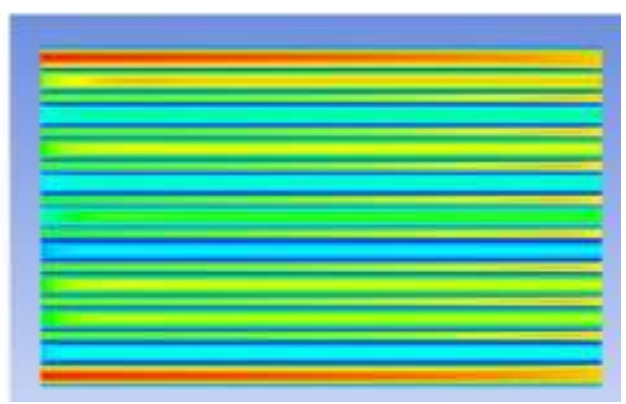

Figure 14: Temperature and velocity contours at different sections for proposed heat exchanger

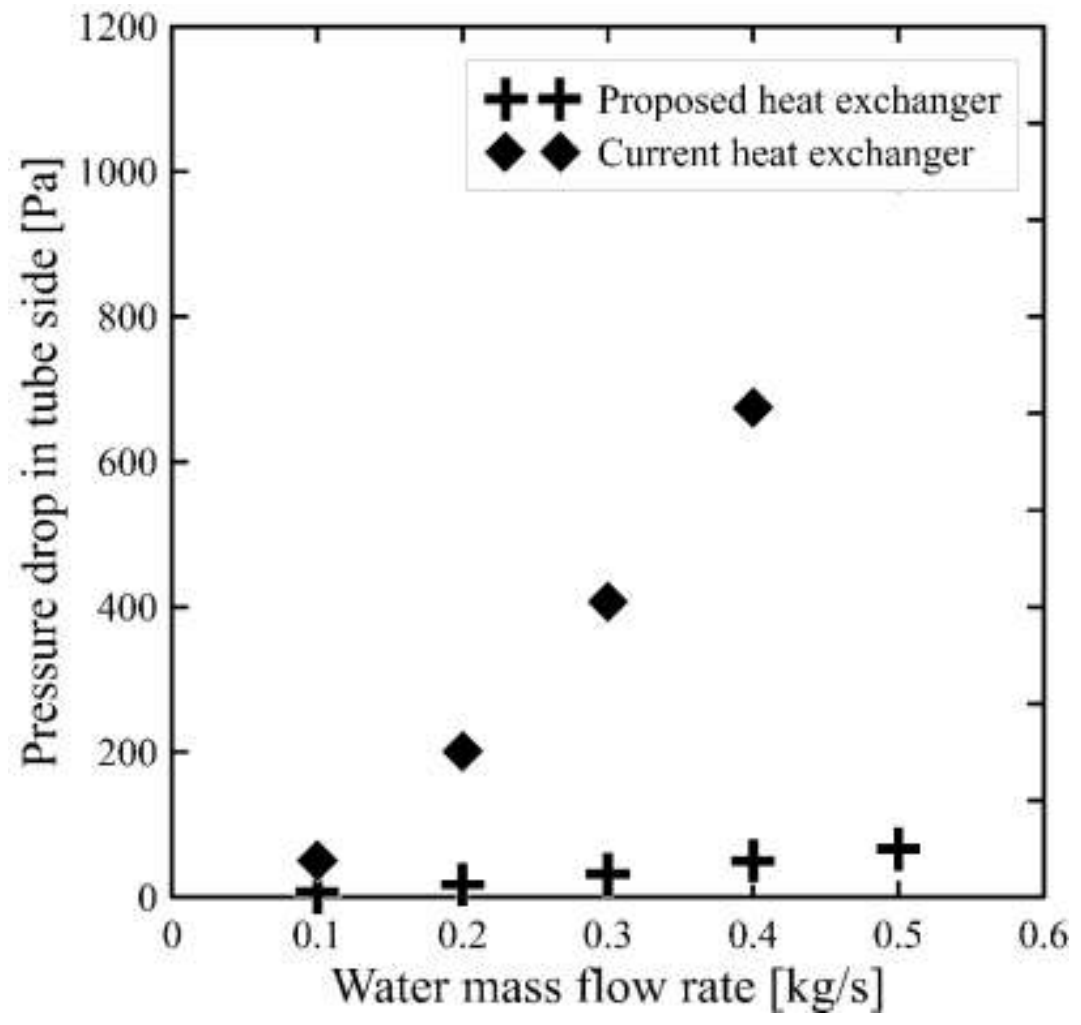

Figure 15: Effect of water mass flow rate on the tubes pressure drop 


\section{CONCLUSION}

The current work introduces a numerical simulation for the heat exchanger to be utilized with incinerator. A proposed heat exchanger was designed and solved numerically using Ansys 2020, commercial software, to be compared with the current fitted heat exchanger. The results show that the proposed heat exchanger has higher operating performance than the already fitted heat exchanger. Form the numerical analysis, and to highlight the dramatic difference in operation, we can select the minimum cooling water flow rate of 0.1 $\mathrm{kg} / \mathrm{s}$ to compare the two heat exchangers' performance. The cooling water outlet temperature was found to be $40{ }^{\circ} \mathrm{C}$ and about to boil for the already used and the proposed heat exchanger, respectively. Moreover, this hot water is available for any other application to get the most benefit of the thermal energy. On the other hand, the exhaust gases' outlet temperature was noticed to be enhanced dramatically, as it was about $1050{ }^{\circ} \mathrm{C}$ and $480{ }^{\circ} \mathrm{C}$ for the current and proposed heat exchanger, respectively. Overall, the authors recommended the new proposed design to be fitted with the incinerator rather than the current fitted to get much better performance.

\section{REFERENCES}

[1] AbdelSalam HA. Operating and Emission Characterstics of a Novel Design Four Chambers Infectious Meat Incinsrator. Int $J$ Res Eng Technol 2013;02:322-8. https://doi.org/10.15623/ijret.2013.0211050.

[2] Dou Y, Ohnishi S, Fujii M, Togawa T, Fujita T, Tanikawa H, et al. Feasibility of developing heat exchange network between incineration facilities and industries in cities: Case of Tokyo Metropolitan Area. J Clean Prod 2018;170:548-58. https://doi.org/https://doi.org/10.1016/j.jclepro.2017.09.147.

[3] Xie R, Li W, Li J, Wu B, Yi J. Emissions investigation for a novel medical waste incinerator. J Hazard Mater 2009;166:365-71. https://doi.org/https://doi.org/10.1016/j.jhazmat.2008.11.029.

[4] Staron P, Kowalski Z, Staron A, Banach M. Thermal treatment of waste from the meat industry in high scale rotary kiln. Int J Environ Sci Technol 2017;14:1157-68. https://doi.org/10.1007/s13762016-1223-9.

[5] Silva R V, de Brito J, Lynn CJ, Dhir RK. Use of municipal solid waste incineration bottom ashes in alkali-activated materials, ceramics and granular applications: A review. Waste Manag 2017;68:207-20. https://doi.org/https://doi.org/10.1016/j.wasman.2017.06.043.

[6] Santoleri JJ. Heat recovery - an economic benefit to hazardous waste incineration systems. J Heat Recover Syst 1983;3:145-55. https://doi.org/https://doi.org/10.1016/0198-7593(83)90006-1.

[7] Sankaran S, Pandey S, Sumathy K. Experimental investigation on waste heat recovery by refinery oil sludge incineration using fluidised-bed technique. J Environ Sci Heal Part A 1998;33:829-45. https://doi.org/10.1080/10934529809376764.

[8] Liu W. Optimizing energy recovery level of a Dutch waste incineration facility. Energy Sources, Part A Recover Util Environ Eff 2018;40:727-33. https://doi.org/10.1080/15567036.2018.1457739.

[9] Kale Shivam B, Kadam Prashant P, Pardeshi Rohansingh G, Karwande Swapnil C. Experimental analysis \& simulation of double pipe heat exchanger. Ijariie 2017;3:2357-67.

[10] Fares M, AL-Mayyahi M, AL-Saad M. Heat transfer analysis of a shell and tube heat exchanger operated with graphene nanofluids. Case Stud Therm Eng 2020;18:100584. https://doi.org/https://doi.org/10.1016/j.csite.2020.100584. 